\title{
IS AMERICAN VIOLENCE A CRIME PROBLEM?
}

\author{
FRANKLIN E. ZIMRING ${ }^{\dagger}$ \\ GORDON HAWKINS ${ }^{\dagger+}$
}

\section{INTRODUCTION}

By long-standing habit, Americans use the terms "crime" and "violence" interchangeably. When we express concern about urban conditions, we commonly talk about "the crime problem" or "the violence problem" as if they were the same thing. When drive-by shootings create newspaper headlines, we demand that our elected officials do something about crime.

As a matter of strict definition, the equation of crime and violence is incorrect. Criminal violence is the intentional and unjustified infliction or threatened infliction of physical injury to a human being. ${ }^{1}$ Crime is a much broader category, referring to all violations of the criminal law. The question we consider in these pages is whether there is actual harm in confusing crime and violence when making policy-whether it is an error to address violence in the United States as a crime problem.

The standard of judgment we propose for this question is a pragmatic one. We are not concerned here with definitional niceties; we are concerned only with the sorts of mistakes that waste material resources and opportunities to save lives and alleviate public fears. We will demonstrate in these pages that regarding

(01996 Franklin E. Zimring and Gordon Hawkins. This article is based on the 1996 Brainerd Currie lecture given by Professor Zimring at Duke University School of Law on March 26, 1996. Much of this material will appear in a volume tentatively titled CRIME Is Nor the PROBLEM: Lethal VIOLENCE AND THE AMERICAN PROSPECT (Oxford University Press, forthcoming 1997).

$\dagger$ William G. Simon Professor of Law and Director of the Earl Warren Legal Institute, University of California at Berkeley.

†† Senior Fellow, Earl Warren Legal Institute, University of California at Berkeley. Former Associate Professor and Director of the Institute of Criminology, University of Sydney.

1. See Panel on the UNDERSTaNdING AND CONTROL OF VIOLENT BEHAVIOR, NATIONAL RESEARCh COUNCIL, UNDERSTANDING AND PREVENTING VIOLENCE 35 (Albert J. Reiss, Jr. \& Jeffrey A. Roth eds., 1993). The requirement that harm be unjustified to be criminal is a long-standing principle of the criminal law. 
crime and violence as interchangeable social problems is a policy mistake of substantial significance.

The empirical justification for regarding American violence as a crime problem can be simply stated. Almost all serious, intentionally inflicted personal injuries in the United States are also violations of the criminal law. Because such violence violates the standards of our criminal code, our violence problem is a crime problen as well. It is, however, an elementary mistake to assume that because most violence is criminal it is also true that most crime is violent.

There is no reason to assume that the large portion of crime in the United States that does not involve violence or the threat of violence-more than $80 \%$-is similar to the less than $20 \%$ of crime that is violent. ${ }^{2}$ There is no reason to assume that the sorts of people who commit violent criminal acts are indistinguishable from the sorts of people who commit nonviolent criminal acts. There is also no reason to assume that the same conditions function as the proximate causes of both violent and nonviolent incidents. Finally, there is no reason to assume that countermeasures that succeed in reducing nonviolent crime will have equivalent success in reducing the incidence and seriousness of violence. Yet those who regard American violence as a crime problem all too frequently do assume that unjustified intentional personal injuries involve the same protagonists, the same causes, and the same solutions as other forms of criminal behavior.

This Article is divided into four parts. Part I provides a context for the consideration of American violence with a series of international coinparisons. Part II presents a sustained analysis of robbery, an offense that conibines elements of theft and violence and which results in thousands of homicides each year in the United States. Part III discusses the degree to which public fear, which we usually think of as a fear of all sorts of crime, is more narrowly focused on the threat of violence. Part IV addresses the errors in policy that are likely when crime and violence are regarded as interchangeable categories.

2. See federal Bureau of INVESTigation, U.S. Dep'T of Justice, CRime in THE UNITED STATES 1992: UNIFORM CRIME REPORTS 8 (1993) [hereinafter 1992 UNIFORM CRIME REPORTS] (reporting statistics for the eight "index crimes" of murder/nonnegligent manslaughter, forcible rape, robbery, aggravated assault, burglary, larceny-theft, motor vehicle theft, and arson). 
Published scholarship on the specific topics covered in this analysis is not yet extensive. Cross-national comparisons of crime are a recent phenomenon, ${ }^{3}$ although international comparisons of homicide have a shightly longer history. ${ }^{4}$ The first multi-national crime victim survey was executed in the late 1980s. ${ }^{5}$ The goals of this Article are to use existing data on violence and crime to determine what Americans really fear and to shape future research on violence, crime, public fear, and public policy.

\section{CRIME AND Violence IN INTERNATIONAL PERSPECTIVE}

\section{A. Los Angeles and Sydney}

Los Angeles is the second largest city in the Umited States, with a 1992 population estimated at 3.6 million by its crime statistics reporting unit. ${ }^{6}$ It is a multiracial, multicultural city on the Pacific coast with a crime rate that by most accounts is its most serious civic problem. ${ }^{7}$ Sydney, located on Australia's Pacific coast, is also a city of approximately 3.6 million. ${ }^{8}$ While multicultural by Australian standards, the etlunic and language mixture falls far short of that in Los Angeles. Crime in Sydney is a serious annoyance, but not a major threat to the continued viability of the city or to the health and welfare of its citizens. ${ }^{9}$

3. See, e.g., James P. Lynch, Crime in International Perspective, in CRIME 11 (James Q. Wilson \& Joan Petersilia eds., 1995); Richard R. Bennett \& James P. Lynch, Does a Difference Make a Difference? Comparing Cross-National Crime Indicators, 28 CRMMNoLOGY 153 (1990).

4. See, e.g., Dane ARCher \& Rosemary Gartner, Violence AND CRIME IN Cross-National Perspective (1984).

5. See Jan J.M. van Dijk \& Patricia Mayhew, Criminal Victimisation in the Industrialised World: Key Findings of the 1989 and 1992 International Crime Surveys, in U.N. INTERREGIONAL CRIME AND JUSTICE RESEARCH INST., UNDERSTANDING CRIME: EXPERIENCES OF CRIME AND CRIME CONTROL 1, 2, U.N. Doc. UNICRI/Publ./No. 49, U.N. Sales No. E.93.III.N.2 (1993) (discussing the first international crime survey, which took place in 1989).

6. See 1992 UNIFORM CRIME REPORTS, supra note 2, at 93 tbl.6.

7. See New Answers Pose Difficult Questions; Survey Redirects Focus to Crime and Related Issues, L.A. Times, Dec. 4, 1994, at B12.

8. See Australian Bureau of Statistics, Year Book Australia 1995, 95 tbl. 5.5 (1994).

9. Proof of a negative is a notoriously difficult task. One of us, Hawkins, has lived in Sydney since 1961 and served as Director of the Institute of Criminology at the University of Sydney for 23 years. There is no survey research in Australia to parallel the Field Poll in California, see infra note 44 and accompanying text; indeed, the absence of such a survey is one datum suggestive of the difference between the level of fear in 
Figure 1 compares the volume of four crimes reported by the police in Sydney and Los Angeles by expressing the number of offenses in Sydney as a percentage of the Los Angeles crime volume. Since the population of the two cities is the same, the crime volume comparison is also a crime rate comparison.

Figure 1

Sydney CRime Volume Compared to Los ANGeles, $1992^{10}$

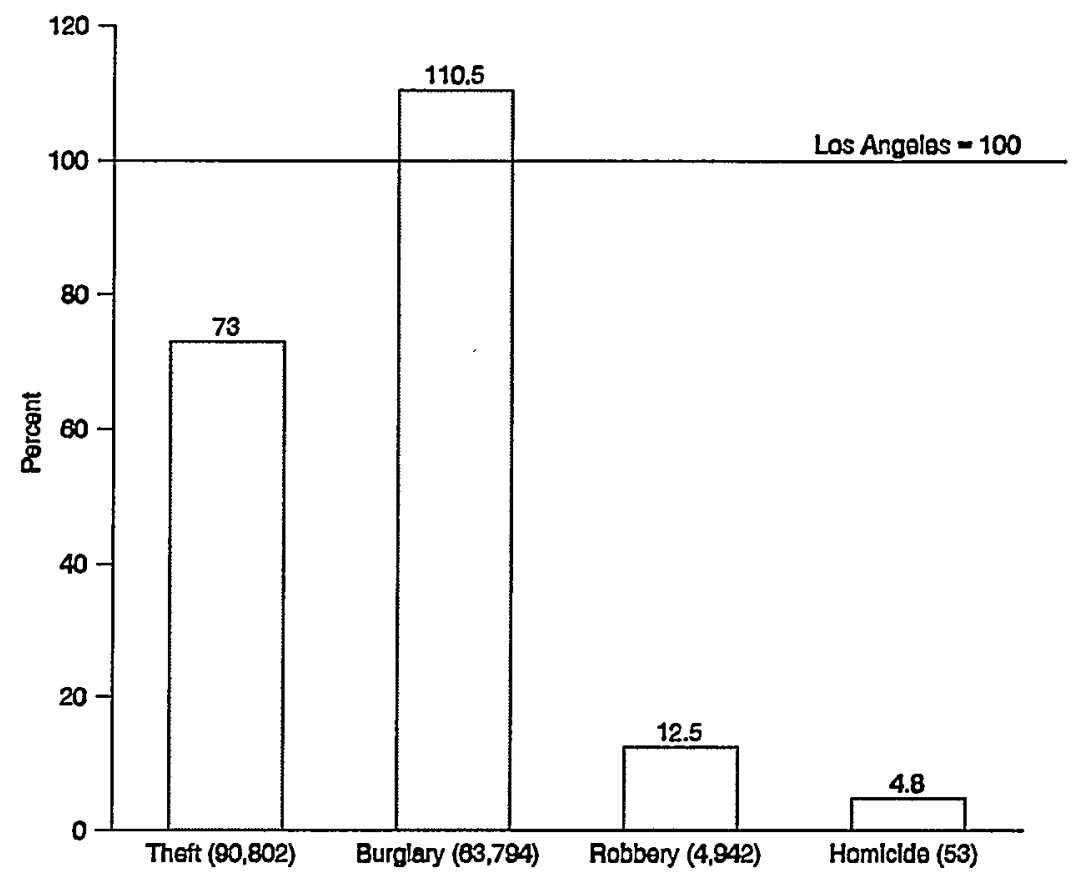

The "theft" category reported at the far left of Figure 1 includes inost forms of stealing that lack elements the law regards as

California and in Sydney. Other indications include the minor role accorded crime rates in Australian state and national political campaigns, and the absence of tabloid stories on the risks of crime and violence (in contrast to frequent, sensational treatinent of individual violent crimes). Although murder has great fascination for the Australian public, we have seen little evidence of personal terror in that country.

10. See 1992 UNIFORM CRIME REPORTS, supra note 2, at 112 tbl.8 (Los Angeles statistics); NEW SOUTH WALES BUREAU OF CRIME STATISTICS AND RESEARCH, ColLECTED DATA FOR 1992 (on file with author) (Sydney statistics). In Figures 1-4, the figures for theft do not include motor vehicle theft. 
increasing the gravity of the offense. Theft is the inost common offense reported in all cities, ${ }^{11}$ and the two jurisdictions under review are no exception. Sydney reports just over 90,000 theft incidents, roughly three-quarters the volume reported in Los Angeles.

Burglary is an aggravated form of theft where the offender breaks and enters private property in order to commit a crime-usually, to steal. ${ }^{12}$ The volume of such crimes in Sydney in 1992 exceeded 63,000, about $10 \%$ inore than the number of burglaries reported in Los Angeles.

The pattern noted for burglary contrasts sharply with robbery, the other major category of aggravated property crime. Robbery is defined as the taking of property from the person of another by force or by the threat of force. ${ }^{13}$ Los Angeles reported 39,508 robberies in 1992, while Sydney reported 4,942, one-eighth the Los Angeles rate. The ratio of burglaries to robberies in Los Angeles is just under 3:2; the ratio of burglaries to robberies in Sydney is greater than 12:1.

The final crime category reported in Figure 1 is for homicides resulting from imtentional imjury. There were fifty-three such offenses reported by the police in Sydney during 1992, a crime volume equal to $5 \%$ of the 1,094 homicides reported by the Los Angeles police that same year. The difference between the two cities im rates of criminal homicide exceeds a factor of ten. The citizens of Sydney can thus live with their higln crime rate in relative comfort because they are not dying from it in large numbers.

Figure 2 reorders the same data used in Figure 1 so that Los Angeles is depicted using Sydney rates as a base.

11. In the United States, larceny-theft accounts for $56 \%$ of all index crime. See FEDeRAL Bureau of INVESTigation, U.S. DEP'T OF JUSTICE, CRIME IN THE UNITED STATES 1994: UNIFORM CRIME REPORTS 8 (1995) [hereinafter 1994 UNIFORM CRIME REPORTS].

12. See Wayne R. LaFave \& Austin W. ScotT, JR., Criminal LaW $\$ 8.13$ (2d ed. 1986).

13. See id. § 8.11. 
Figure 2

Los ANGeles Crime Volume COMPAREd to SydNEY, $1992^{14}$

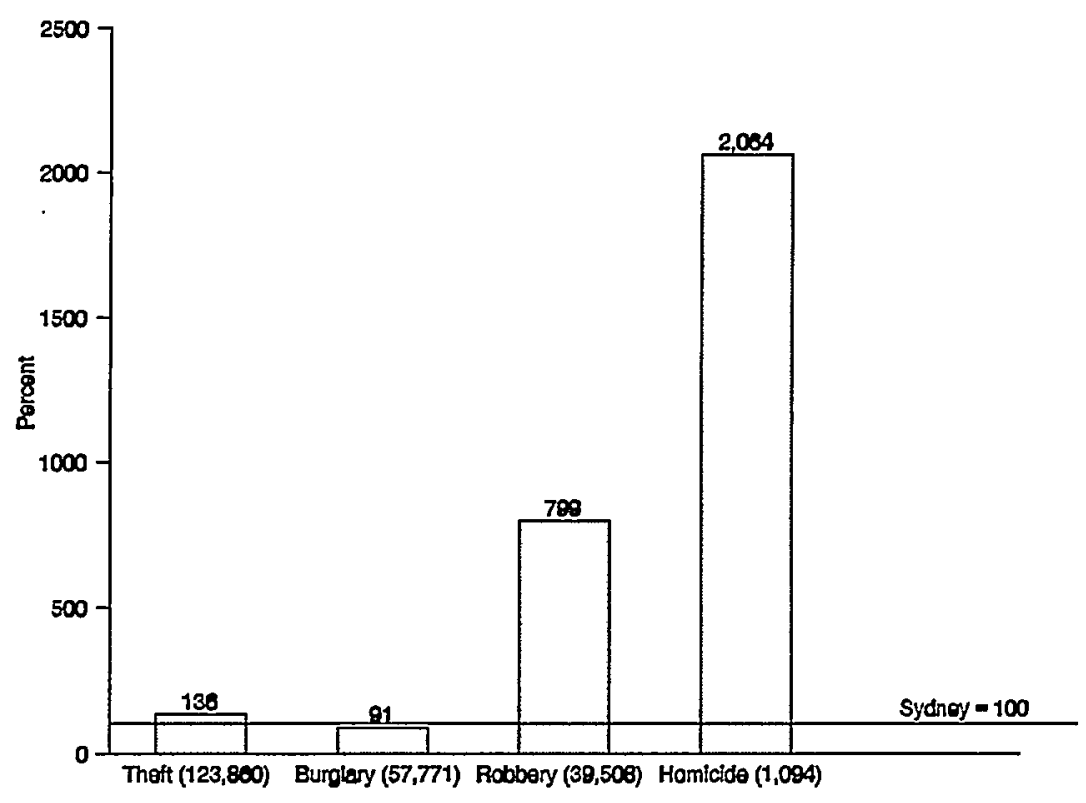

Figures 1 and 2 carry visual, statistical, and substantive lessons about crime and violence in the two cities. Visually, the use of Sydney rates as the basis of comparison means that the scale of the figure must be expanded: the theft and burglary representations are dwarfed by the distended bar values necessary to show Los Angeles violent offenses on a Sydney scale.

The statistical conclusion one draws from an inspection of Figures 1 and 2 is that the nature of the coinparison between Sydney and Los Angeles depends on what is being coinpared. For theft and burglary the two cities are quite similar. For robbery, they are vastly dissimilar; for homicide, the 20:1 difference is huge.

The substantive conclusion to be drawn from the statistical pattern can be stated in two ways. First, it seems beyond dispute that what separates the two cities is not so much the amount of

14. See 1992 UNIFORM CRIME REPORTS, supra note 2, at 112 tbl.8 (Los Angeles statistics); New SOUTH WALES BUREAU OF CRIME STATISTICS AND RESEARCH, COLLECTED DATA FOR 1992 (on file with author) (Sydney statistics). 
crime they experience, but rather the character of the crime they experience. However, we think the point can be put more sharply: what is distinctive and threatening in Los Angeles is not a crime problem, but a problem of lethal violence.

\section{B. New York and London}

New York is the largest city in the United States, with a population just past seven million. ${ }^{15}$ London has a city population of about 6.6 million. ${ }^{16}$ Figure 3 shows London crime rates per 100,000 using New York rates as a standard for comparison.

Figure 3

LONDON CRIME RATES COMPARED TO NEW YORK, $1990^{17}$

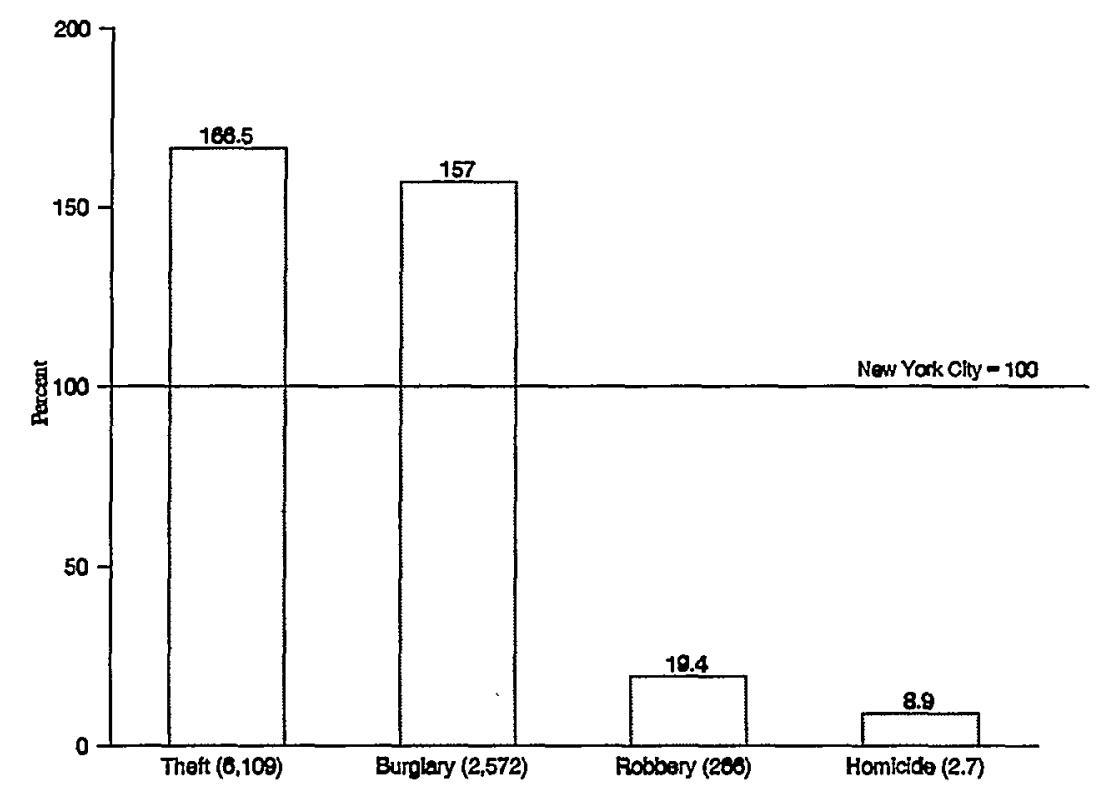

15. See federal bureau of Investigation, U.S. Dep't of Justice, Crime $\mathbb{N}$ THE UNITED STATES 1990: UNIFORM CRIME REPORTS 101 tbl.6 (1991) [hereinafter 1990 UNIFORM CRIME REPORTS].

16. See 2 EUROPA WORLD YEARBOOK 2675 (31st ed. 1990).

17. See 1990 UNIFORM CRIME REPORTS, supra note 15, at 101 tbl.6 (New York statistics); RESEARCH AND STATISTICS DEP'T, GREAT BRITAN HOME OFFICE, COLLECTED DATA FOR 1990 (on file with author) (London statistics). Rates are per 100,000. 
The statistical comparison in Figure 3 is even more surprising than that concerning Los Angeles and Sydney, and to the same effect. London has $67 \%$ more theft than New York and a burglary rate that is $57 \%$ higher. But the robbery rate in London is less than one-fifth the robbery rate in New York, and the homicide rate in London is less than one-tenth the New York figure. Figure 4 shows New York rates compared to London.

Figure 4

NeW YoRK CRIME RATES COMPAREd to LONDON, $1990^{18}$

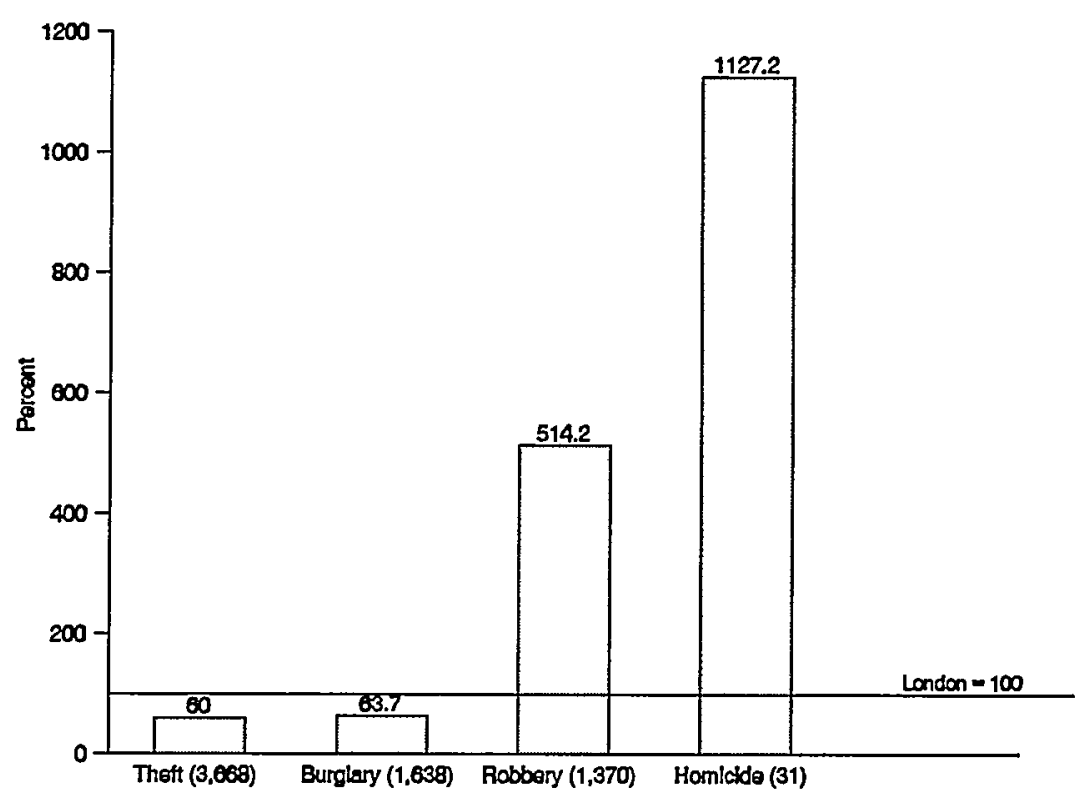

The total number of offenses per 100,000 citizens in Figure 4 is slightly higher in London than in New York. If overall crime rates were the problein, Londoners should live in greater fear or New Yorkers in relative complacency. But with a robbery rate five times those of London and a death rate eleven times as high, the population of New York is far from comfortable. Violence is New

18. See 1990 UNIFORM CRIME REPORTS, supra note 15, at 101 tbl.6 (New York statistics); RESEARCH AND STATISTICS DEP'T, GREAT BRITAIN HOME OFFICE, COLLECTED DATA FOR 1990 (on file with author) (London statistics). Rates are per 100,000. 
York's problem, not crime, and lower rates of general theft are no consolation for huge death toll differences.

If readers are wondering if these data are selective and misleading or if the numbers are skewed by the peculiarities of different reporting systems, the next set of comparisons should provide some reassurance that our city comparisons are part of a broad and consistent pattern.

\section{Twenty Countries}

We can show clearly that America's special problem is violence and not crime by comparing the results of a twenty-nation survey in which citizens reported their crime victimization rates with World Health Organization data on death from assaults for the same nations. Figure 5 shows the violent death rates for the five nations with the highest overall crime levels, then the next highest group of five, and so on.

There are several imdications that a country's crime rate is substantially independent of its violence rate. First, the variation in violent death rate is quite large within each separate crime rate category. Within the group of highest crime nations, the homicide rates vary by a factor of ten, in the next group by a factor of five, in the third group by a factor of three, and in the lowest crime group by a factor of eight. In contrast, the median homicide rates for the different crime categories are clustered between 1.3 and 2.2 per 100,000 . So knowing which general crime rate category a country belongs in does not tell you much about that country's rate of violent death.

Similarly, a country's rate of violent death does not predict much about its crime rate. The country with the lowest rate of violent death (England) has a crime rate just over average. The country with the next lowest rate of violent death is Japan, which has the lowest crime rate. Tied for third lowest violent death rate are the Netherlands and Spam, which are in the highest and second highest crime rate groups, respectively. The pattern is just as opaque at the top of the violence distribution. The most violent country, the Umited States, has a high crime rate as well. The next most violent country, Northern Ireland, is in the lowest crime rate group.

This data set provides a multimational illustration of the central point that lethal violence is the problem in the Umited States. 
It shows the United States clustered with other industrial countries in crime rate, but head and shoulders above the rest in violent death.

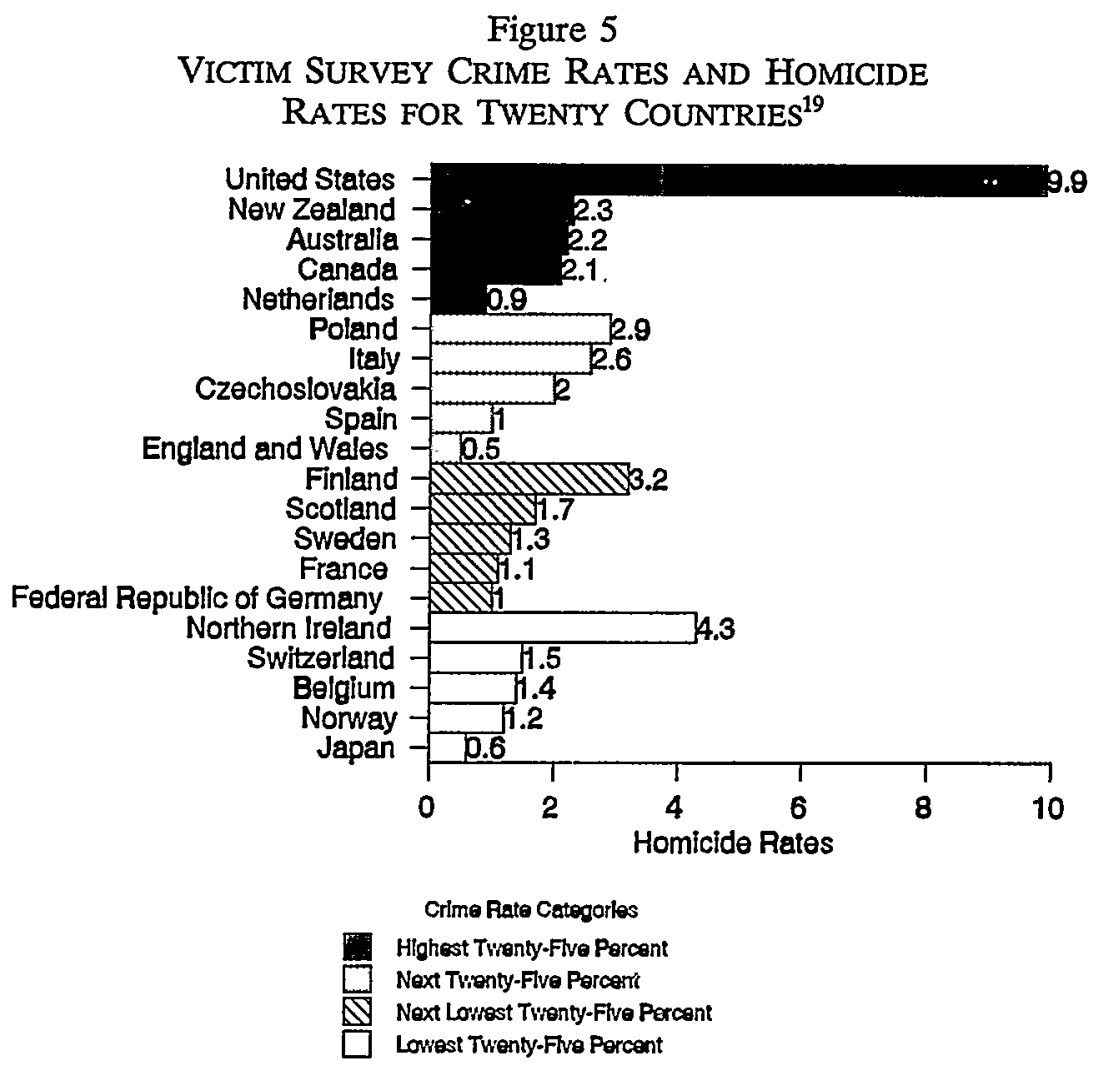

Judging from Figure 5, the United States has about the same rate of crime and prevalence of criminality as the Netherlands and Australia. But ours is by far the more dangerous country to live in. We currently have a Netherlands-size crime problein and a king-size violence problem that threatens the social organization of our cities. Which problem sliould we try to solve?

19. Van Dijk \& Mayhew, supra note 5, at 26 tbl.3 (victim survey crime rates); WORLD HEALTH ORGANIZATION, WORLD HEALTH STATISTICS passim (1990) (homicide rates). 


\section{AMERICAN ROBBERY: CRIME OR VIOLENCE?}

Robbery is both a very important part of American violence and also representative of most violence in the United States. Indeed, it is not possible to comprehend violence in America without understanding the inotivation and outcomes of American robbery. And it is not possible to understand robbery in America-why it occurs so often, why it kills so frequently-without coming to terms with violence as a phenonienon separate fron1 the motivations and conduct norms that govern most forms of crime.

The standard legal definition of robbery is the taking of property by force or by threat of force. ${ }^{20}$ It is thus both a property crime and a crime of violence. It is a property crime that, unlike theft and burglary, directly threatens the physical security of its victims. It is a crime of violence that, in all its heterogeneous forms, occurs more than half a million times a year in the United States, striking many more victims than rape $^{21}$ and reaching across boundaries of social and econormic class far more often than does serious assault, which usually involves victims and offenders who are acquainted. ${ }^{22}$ Robbery is the stranger-to-stranger crime that most frequently results in victim death and injury in the United States, accounting for over 2,000 deaths per year, or nearly $50 \%$ of all the killings that are classified by the Federal Bureau of Investigation as "felony murders."

If any category of life-threatening behavior would appear to support the conclusion that American violence is a natural outgrowth of high levels of American crime, it would be robbery. Material gain is the objective of this behavior, unlike inost violence, so it is proper to think of the behavior that leads to the risk of bodily injury in robbery as the means used by the actor rather

20. See LAFAVE \& SCOTT, supra note $12, \S 8.11$.

21. See Bureau of Justice STATISTICS, U.S. Dep'T OF Justice, SOURCEBOOK OF CRIMINAL JUSTICE STATISTICS 1993352 tbl.3.107 (Kathleen Maguire \& Ann L. Pastore eds., 1994) [hereinafter 1993 SOURCEBOOK]. Over 672,000 robberies and about 109,000 rapes occurred in 1992. See id.

22. According to the Bureau of Justice Statistics, $53.5 \%$ of incidents of aggravated assault with injury occur between non-strangers. See BUREAU OF JUSTICE STATISTICS, U.S. DeP'T OF JUSTICE, SOURCEBOOK OF CRIMINAL JuSTICE STATISTICS 1994235 tbl. 3.11 (Kathleen Maguire \& Ann L. Pastore eds., 1995) [hereinafter 1994 SOURCEBOOK].

23. See 1993 SOURCEBOOK, supra note 21 , at 380 tbl.3.125. Of the 4,887 felony murders known and suspected by the pohice in 1992, 2,254 occurred during known robberies. See id. 
than as his end. There is thus a similarity between robbery as an instrumental behavior and other criminal conduct designed to achieve the unauthorized taking of property. Yet two puzzling features of robbery in the United States point to the conclusion that the injury and death associated with American robbery should not be considered a natural consequence of the high volume of crime in the United States. First, why is robbery the crime of choice for so many offenders in the Umited States when other forms of property crime are more lucrative and less dangerous? Second, why do robbery events so frequently lead to injury and death? This high death rate is a mystery because a dispassionate analysis of failure to obtain property froin a stranger who refuses to cooperate should lead an unthreatened robber to disengage and seek another victim.

\section{A. An Irrational Crime?}

Those who believe that criminal behavior is governed by rational principles find it hard to explain the persistence of high rates of robbery in the United States. ${ }^{24}$ The inuggings and armed robberies that alarm city dwellers turn out to be a terrible way to make a living. Only a minority of American robberies are directed at cominercial establishments with large amounts of cash. ${ }^{25}$ Even the rewards for such hard-target robberies are far from commensurate with the risks involved. Many commercial establishments are well-defended against robbery, with alarm systems and armed guards. The arrest rate for commercial robberies is relatively high, ${ }^{26}$ and the inore lucrative the robbery target, the greater the chance of detection. The majority of bank robberies are cleared by arrest, even in cities where the clearance rate for burglaries is no more than $15 \%{ }^{27}$ The unplanned street robberies that constitute

24. The position that criminal behavior is governed by rational principles is associated with the work of Cesare Beccaria. See, e.g., CESARE BECCARIA, ON CRIMES AND PUNISHMENTS (Henry Paolucci trans., 1963) (1764). Its modern expression is most associated with Gary Becker, whose 1968 article on the economics of crime and punishment has been widely influential. See Gary S. Becker, Crime and Punishment: An Economic Approach, 76 J. POL. ECON. 169 (1968).

25. See 1993 SOURCEBOOK, supra note 21, at 392 tbl.3.143.

26. See Franklin E. Zimring \& James Zuehl, Victim Injury and Death in Urban Robbery: A Chicago Study, 15 J. LEGAL STUD. 1, 27 tbl.18 (1986) [hereinafter Chicago Study].

27. Compare The Oregon Bank Robbery Crisis: Finding New Law Enforcement Strategies: Hearing Before the Subcommittee on Regulation, Business Opportunities, and Energy 
the majority of all robberies ${ }^{28}$ generate a risk of arrest that is smaller than that for commercial robbery but larger than the risks associated with larceny or burglary. ${ }^{29}$ Moreover, the cash rewards for street robbery are usually pitifully small-under $\$ 250$ on average. ${ }^{30}$ Those who persist in robbery are almost always eventually caught and usually imprisoned..$^{31}$ On a risk-reward basis, no crime agamst property makes less sense in the United States than robbery.

Yet it is precisely the $\$ 250$ armed robbery that kills thousands of victims a year, that causes prisons to overflow, that makes us appoint blue-ribbon commissions to study the crime problem. Why then does this behavior persist in the streets of urban America?

The high volume of robbery in the United States certainly seems irrational if we think of potential offenders as motivated only by the desire to acquire property when making choices among the various possible criminal means of acquisition. This model of choice assumes no skill requirement on the part of the potential offenders for either violent or nonviolent means of acquisition. It further assumes that there is no special utility-enjoyment, for example-associated with a particnlar criminal means of acquisition.

But what if the domination of another human being by threat has positive utility for a potential offender? $?^{32}$ Or what if an

of the House Committee on Small Business, 101st Cong., 97-98 (1989) (statement of Danny O. Coulson, Federal Bureau of Investigation) (approximately $75 \%$ of bank robberies are cleared in Portland, Oregon) with CRIME IN THE UNITED STATES 1990, supra note 15, at 163 tbl.20 (average clearance of burglaries in cities of Portland's size is under $15 \%)$.

28. See 1993 SOURCEBOOK, supra note 21, at 392 tbl.3.143.

29. See Frankin E. Zmiring \& Gordon Hawkins, InCAPACITATION: Penal ConFINEMENT AND THE RESTRAINT OF CRIME 89 tbl.5.1 (1995) [hereinafter INCAPACITATION].

30. See, e.g., Bureau of Justice Statistics, U.S. Dep'T OF Justice, SOURCEBook of CRIMINAl Justice Statistics 1992 258-59 tbl.3.16 (Kathleen Maguire et al. eds, 1993) [hereinafter 1992 SOURCEBOOK].

31. See MARK A. Peterson et Al, Who Commrts CRIMEs: A SuRVey of Prison INMATES 21 tbl.9 (1981). This inmate survey contains powerful evidence of the distinctly high risks of robbery as a criminal enterprise. Thirty-four percent of the prisoners surveyed confessed to having committed armed robbery, and $35 \%$ had been convicted of robbery. See id. In contrast, while $46 \%$ confessed to having committed burglary, only $15 \%$ had been convicted of that crime; and though $39 \%$ confessed to having sold drugs, only $18 \%$ had been convicted of any type of drug offense. See id. Assuming the relative risks for inmates are equivalent to those for all offenders, the chances of escaping arrest for repeat robbery are quite low.

32. See JACK Katz, Seductions of Crmm: Moral and Sensual attractions 
offender's habits and skills render him better prepared to acquire property by intimidation than by stealth? Only in these circumstances-when robbery is easier than other crimes or when it provides noninstrumental satisfaction to the offender-does the election to commit robbery approach rational behavior under current conditions.

But if either the possession of assaultive habits and skills or the enjoyment of intimidation are necessary to explain the American tendency toward robbery, then high levels of robbery should best be seen as a spillover from general tendencies toward violence, and not as a separate behavioral system operating independently of other factors that condition violent behavior in a social systein. On this view, robbery should be regarded as the violent man's property crime; and the best predictor of the level of robbery im a particular setting may not be the general level of property crime, but rather the general level of violence.

\section{B. The Mystery of Robbery Killings}

The second puzzle concerns the high rate of injury and death associated with robbery in the United States, particularly when the robbery victim is unwilling to hand over money or property. The injury or death of a robbery victim is not difficult to explain when the victim responds with resistance of a kind that puts the robber in jeopardy. And studies have shown that death rates of victim mjury increase in such circumstances. ${ }^{33}$ But the victim death rates also increase when the person threatened simply does not have any money or property to give up. ${ }^{34}$ Since both the risk of apprehension and the potential punishment escalate when the victim is killed, ${ }^{35}$ the rational robber would be well-advised to respond to such circunistances by avoiding conflict and seeking another victim.

Yet frequently a frustrated robber uses lethal force in response to noncooperation by a victim whose resistance poses no immediate threat whatever to the robber. In the Zimring and Zuehl study of urban robbery im Chicago, the most significant

IN DOING EVIL 167 (1988) (discussing a survey of prison inmates in which $40 \%$ of the "violent predators" agreed that the thrill of confronting an armed victim was part of the motivation to commit the crime).

33. See Chicago Study, supra note 26, at 17-18.

34. See id.

35. See id. at 27 tbl.17. 
predictor of death in urban robbery was whether the victim was active in not cooperating with his or her assailant. "Active noncooperation" cases included refusal and flight, as well as resistance with physical force. ${ }^{37}$ These cases had a death rate fourteen times as great as robberies where there was no resistance. ${ }^{38}$ Cases where the victim denied having any noney were about twice as likely to result in the death of the victim as cases in which the victim offered no resistance, but only one-seventh as lethal as active noncooperation. ${ }^{39}$

Why would a robber shoot a stranger who refused to hand over property when a killing increases the offender's chances of being caught by a factor of four ${ }^{40}$ and, moreover, threatens the law's niaximum punishment?

We think that one fruitful approach to this problem would be to regard all attempted robberies as potential social conflicts. Even if the offender and victim are strangers initially, the victim's refusal to cooperate in the robbery creates a contest of wills that may explain the high rate of lethal violence in cases of refusal. The robber experiences refusal as a challenge to his authority and credibility. All too often this challenge is met with life-threatening violence. The most plausible reason why refusal to cooperate with a robber generates a high risk of the use of lethal force is that the offender takes refusal personally.

If the foregoing analysis is an accurate explanation of the death rate from robbery, the common theme in robbery assaults on strangers and conflict-motivated assaults between acquaintances is apparent. Violent assault in the United States is very often a matter of maintaining status, combatting disrespect, and standing up to challenges to personal authority and "manhood."41 The same motivation and the same kind of conflict probably are found

36. See id. at 17-19. However, the victim's resistance may sometimes be a result, rather than a cause, of the robber's intent to injure. See id. at 19.

37. See id. at 17-18.

38. See id. at 18.

39. See id.

40. See id. at 27 tbl.17.

41. The gender-specific term "manhood" is used intentionally here: according to the FBI's Uniform Crime Reports, $86 \%$ of those arrested for violent crimes in 1994 were male. See 1994 UNIFORM CRIME REPORTS, supra note 11, at 217; see also KATZ, supra note 32 , at $237-47$. 
in a high proportion of the robbery attempts that result in serious injury and death.

This background permits us to specify in some detail what we mean when we say that the death rate from robbery in the United States should not be regarded as a crime problem. The acquisition of property by criminal means is as widespread in London and Sydney as it is in New York and Los Angeles; London has just as much crime as New York and just as many criminals. ${ }^{42}$ But the consequences of crime in other developed nations are relatively trivial. The crime problem in most mdustrial nations is loss of property, not danger to life. In Sydney, the chance of being killed by a robber, burglar, or purse snatcher in 1992 was less than 1 in $500,000.43$

In the Umited States, however, it is the overlap of the tendency to favor the use of personal force with the desire to acquire property by criminal means which results in high rates of robbery, imjury in robbery, and killing in robbery. As we have dernonstrated, the preference for robbery is due neither to lower risk nor to greater material rewards than other forms of property crime. Thus, it is more appropriate to regard violent robbery as an aspect of a larger propensity toward violence than it is to view it as part of a broader pattern of crimes against property. Given the considerable risks involved, and the relatively modest rewards, robbery is the violent man's property crime. A high volume of robbery therefore inust reflect the character and tastes of the individuals who perpetrate it-and perhaps of the society from which they come.

\section{CRIMe, Violence, AND Citizen Fear}

The sharp contrast between levels of violent crime in Sydney and Los Angeles invites us to consider the relationship between rates of life-threatening personal violence and public perceptions of the seriousness of crime as a problem. As measured by the political importance of crime as an election issue, or the degree to which fear of crime is mentioned as a major disorganizing influ-

42. See supra Part I.A-B.

43. The New South Wales Bureau of Crime Statistics and Research reported two burglary killings and five robbery killings in the Sydney statistical division, with a population of 3.6 million. See Letter from Roseanne Bonney of the New South Wales Bureau of Crime Statistics and Research to Franklin Zimring (Aug. 24, 1995) (describing analysis performed by Bonney) (on file with author). 
ence on urban life, Sydney does not seem to have a significant crime problem. To be sure, housebreakers are not popular figures in New South Wales and complaints about crime are quite common-but terror is not.

Los Angeles is a city where fear of crime and of criminals is arguably the single most important social and political issue for the majority of citizens. Public opimion surveys reflect this difference to some degree, but they do not capture the palpable difference between crime as an annoyance im Australia and crime as a fundainental threat to social life in Los Angeles. The annual statewide Field Poll, which ranks Californians' concerns on approximately thirty different issues, consistently reports that crime is at or near the top of the list. ${ }^{44}$ Concern about policy toward criminals dominated the 1994 California elections to an extent that would be unthinkable at any level of government in Australia. ${ }^{45}$ The intensity of citizen concern in California is also reflected in the demand for substantial changes in criminal justice policy. The prison population in California grew over $400 \%$ in the fifteen years prior to the 1994 elections, ${ }^{46}$ but California voters nevertheless overwhelmingly supported a referendum in 1994 that required a twenty-five-years-to-life sentence for anyone convicted of a third felony if the offender's previous convictions had been as serious as housebreaking. ${ }^{47}$

Since general levels of nonviolent crime in Sydney and Los Angeles are closely similar, why not conclude that it is levels of lethal violence rather than of crime generally that determine the degree of public fear? Why else would similar numbers of criminals and rates of crime lead to such a sharp cleavage im public response? The question is an important one, but far from easy to answer with confidence. Evidence regarding the relationship be-

44. See Edward Epstein, Californians List Crime No. 1 Issue; Survey's Results Reflect Election-Year Campaign Trend, S.F. CHRON., Aug. 3, 1994, at A15 (crime rated top concern in 1993, 1994); Job Worries Recede in State Poll, SAN DIEGO UNION-TRIB., Oct. 4, 1995, at A11 (crime tied with schools as second most important concern in 1995; AIDS rated top concern).

45. See, e.g., Dan Smith, Gov. Wilson's Theme: Crime, Immigration, PRESS-ENTERPRISE, Nov. 3, 1994, at A1.

46. See Franklin E. Zimring \& Gordon hawkins, Prison Population and Criminal Justice Policy IN California xi, 5 (2d prtg. 1994) [hereinafter Prison POPULATION].

47. See Dan Morain \& Virginia Ellis, California Elections/Propositions: Voters Approve "Three Strikes" Law, L.A. TIMES, Nov. 9, 1994, at A3. 
tween rates of different types of crime and public attitudes is surprisingly sparse, and the specific question of the influence on attitudes of rates of violence rather than rates of crime generally lias not been systematically addressed.

There are two different issues involved in determining the relationship between rates of violence and public fear: the salience of violence as a focal point for citizen fear and the influence of rates of violence on levels of public concern about violence. On the first issue the answer seeins clear: when citizens are afraid of crime, it is life-threatening personal violence that dominates their attention. On the second issue, the evidence is far from clear. While the objective risks of violence undoubtedly influence the level of public fear, so also do inany other variables. And the extent to which different levels of public concern can be explained by differences in objective risk is not known.

To clraracterize concern about serious personal violence as the dominant image in public fear of crime may seein like an overstatement. Residential burglary does not entail great danger to life, ${ }^{48}$ but residential burglary is a crime that Californians greatly fear. Including residential burglary as a triggering felony in the California "three strikes" sentencing proposal was vigorously supported by the public even though it tripled the cost of the program. ${ }^{49}$ Is this not evidence that nonviolent threats are as salient to individuals as violent ones?

Probably not. Public fear of burglary is most likely associated with images of the worst thing that could happen in the course of a lousebreaking, rather than the kind of things that usually do liappen when burglars appear. The inajority of burglarized dwellings are unoccupied at the time of the invasion..$^{50}$ But the image of burglary which provokes public fear is of the burglary of an occupied dwelling. The great inajority of burglars would react

48. We compared the number of deaths resulting from burglary reported in the FBI Supplemental Homicide Reports for 1992 with the number of reported burglaries and estimated 0.7 deaths per 10,000 burglary incidents. See FRANKLIN ZIMRING \& GORDON HAWKINS, CRIME IS NOT THE PROBLEM: LETHAL VIOLENCE AND THE AMERICAN PROSPECT ch. 4 (forthcoming 1997). The same analysis estimated a robbery victim death rate of 34 per 10,000 acts, or 50 times the burglary death rate. See id.

49. Franklin E. Zimring, "Three Strikes" Law Is Political Fool's Gold, CHRISTIAN SCI. MONITOR, Apr. 11, 1994, at 23.

50. Only about $10 \%$ of all burglaries involve occupied dwellings. See JAMES D. WRIGHT ET AL., UNDER THE GUN: WEAPONS, CRIME, AND VIOLENCE IN AMERICA 139 (1983). 
nonviolently in any interaction with household members. ${ }^{51}$ But the image of burglary that produces high levels of citizen fear finds the victim defenseless in bed and at risk of being murdered. It is the worst-case burglar that engenders high levels of public fear regarding residential burglary.

But the worst-case burglar does not explain the contrast between Sydney and Los Angeles. Why would liousebreakers provoke much more fear im Los Angeles than in Sydney? One reason might be the fact that many people have liomogeneous images of "the criminal"- they do not think of robbers and burglars as different sorts of people, but rather imagine the criminal offender who threatens their sense of security as a composite of the personal characteristics of the criminal offenders that they liave heard about. If this homogeneity-of-image phenomenon exists, citizens who live in environments where liomicidal attacks are common will fear all kinds of contact with criminal offenders much more than citizens whose composite image of the criminal offender is formed $i \mathrm{~m}$ an environment that exhibits less lethal violence.

In an urban environment where armed robbery frequently leads to the death of victims, the purse snatcher and the burglar will acquire much of the threatening character of the robber because the composite, generalized image of the criminal that conditions public fear acquires the characteristics of the lethal armed robber. The fear generated by the kidnap and murder of Polly Klaas $^{52}$ provokes long sentences for residential burglars because the burglar in the citizen's scenario has acquired the characteristics of Polly Klaas's killer.

High levels of interpersonal violence could thus generate a process we call categorical contagion, whereby citizens come to fear many forms of criminal behavior because they imagine that they are all committed by extremely violent protagomists. Lower general levels of violence may be associated with less pressure toward categorical contagion because there are fewer mcidents of

51. See supra notes $48 \& 50$.

52. The abduction and murder of 12-year-old Polly Klaas by Richard Allen Davis, an ex-convict on parole for a previous kidnapping with a criminal record that included multiple felony convictions, sparked the popular campaign for the "three-strikes" legislation and constitutional amendment in California. See Mary Curtius, Jury Recommends Death Penalty for Polly Klaas' Killer, L.A. TMES, Aug. 6, 1996, at A1. 
frightening violence to condition the citizen's image of the criminal threat.

Processes of categorical contagion may operate im social life well beyond the frontiers of the criminal code. Concern about vulnerability to assault can produce fear of a wide variety of social encounters, mcluding rudeness and incivility and even face-to-face contact with strangers in the streets if those strangers are seen as threatening. If a person carries profound feelings of physical vulnerability into a social setting, daily activities are disrupted as ambiguous or even ninocuous behavior produces substantial anxiety. This process of categorical contagion also may work in reverse, so that a lingh level of anxiety about strangers or face-toface interaction expresses itself as a fear of becoming a victim of a violent crime. Just as substantial anxieties about being robbed or attacked inay inake a person apprehensive about encountering strangers, an intense but nonspecific fear of strangers or foreigners or minorities may produce more specific concerns that the subjects of apprehension intend to commit assault.

When arguing for physical vulnerability as a citizen's core concern, we do not want to suggest that this preoccupation will be found to the same degree at all stages of social and economic development. It is ironic that modern industrial nations do a better job of protecting their citizens' property interests from criminal threats than of protecting their bodily security. Insurance can provide coinpensation for the loss of niost property imterests. Moreover, because citizens in a modern state do not keep all their inoney under their mattresses, many property imterests are not vulnerable to trespassory taking. Citizens can keep their money in banks and the state can provide depositors with insurance that will repay thein if the bank fails. The private sector provides mechanisins of imsurance to purchase replacenients for automobiles that are stolen or for personal property that is carried away by burglars. But even where it exists, financial compensation for the victims of violence cannot restore what is lost in the same sense that the insurance coinpany can enable one to purchase a new Chevrolet. Life imsurance, of course, can provide financial benefits to the family or dependents of the victim. This is important, but the deceased is not brought back to life. For this reason, the more successful a society is in providing its meinbers with security of property, the more concentrated its citizens' fear of violence will be. 
If concerns about personal safety are paramount to citizens of a modern industrial society, what factors predict variations $\mathrm{m}$ the level of such concerns? This is a complicated question and one that has not been squarely addressed in the social science literature on the fear of crime. We would expect at least three major influences on the level of fear regarding serious crime: 1) the amount and seriousness-i.e., the actual risk-of violent crime; 2) the level of fear-arousing social conditions in the immediate physical environment of the subject; and 3) the amount and perceived seriousness of fear-arousing cues in the mass media and the personal social universe of the subject.

How important is actual risk in the mix of cues that produces varying levels of citizen fear of violence? We would expect variations in the actual risk of serious violence to be a major determinant of levels of fear, exerting influence in a variety of ways. The higher the rate of serious violence, the greater the chance that the average citizen will have been a victim of violence or will have some social relationship to a victim of violence. The greater the risk of serious violence, the stronger the associations between fear of this violence and cues in the citizen's immediate social environment: the higher the number of people sliot, stabbed or mugged, the more fearful citizens are of dilapidated buildings or threatening-looking strangers. Finally, we would expect both that the number of social cues and the amount of media attention to violence would be directly influenced by the rate and seriousness of violence (although we are more confident of the relationship between risk and the fear-arousing contacts of the citizen than in the relationship between risk and the amount and character of media cues about violence).

We would expect to find a positive association between risks of life-threatening violence and the amount of public fear. But variations $\mathrm{m}$ risk are by no means the only influences on levels of public fear of violence. Processes of categorical contagion will link levels of public fear of violence to fluctuations in other social conditions that make people anxious and insecure. Furthermore, to the extent that the character and quantity of media attention to violence fluctuates independently of trends in actual risk, this variable will also influence levels of fear, particularly among groups that lack more direct experience with violence. It thus seems probable that fear of violence in 1990s America is to some 
extent a creation of the media, independent of changes in other social conditions.

What we do not know is the maximum level of public fear that can be produced and sustained in an environment of general social anxiety, but low levels of lethal interpersonal violence. An attempt to import an American-style "law and order" campaign into the electoral politics of a nation with low deatli rates from violence miglit tell us whether fear can be sustained without high rates of death.

A similar issue concerns the generality of fear induced by mcivility and disorder. James Q. Wilson and George Kelling have argued persuasively that indications of incivility and disorder produce citizen fear. ${ }^{53}$ One reason such indications could arouse fear is that they convey to many people the inessage that they are vulnerable to more direct and inore violent predation. But will the level of fear produced by disorder and incivility be as great where rates of lethal violence are low as it will be where those rates are high? The extent to which fear of lethal violence and fear of concentrated threats to public order feed off each other should be a priority concern in the social psychology of crime.

\section{Crime Policy as Violence Policy}

Life-threatening violence is, of course, against the public policy of the inodern state in all but exceptional cases, but so are a wide variety of acts that range from larceny to illegal drug consumption to sexual exploitation of children. What then is wrong with public policy that treats violence as one of the many crime probleins that are best addressed by police, prosecutors, and prisons?

This section discusses sone of the difficulties associated with misdefining American violence as solely a crime problein. In pursuing this analysis we do not deny that crime in the United States is destructive, costly, and disorganizing. Rather, we argue that it is the violent strain in American social life which causes the special destruction and disorganization produced by American crime.

There are three hazards associated with making general crime control policy the dominant governmental and social response to

53. See James Q. Wilson \& George L. Kelling, Broken Windows, ATLANTIC MONTH* LY, Mar. 1982, at 29. 
violence: 1) the narrowness of a crime policy perspective; 2) the failure to address noncriminal sources of potential violence; and 3 ) the diffusion and loss of priority that result when violence is principally addressed as part of the American crime problem. Part A will provide a general outline of these objections. Part B will illustrate many of these problems with the historical record of recent American "wars" on crime.

\section{A. Three Objections}

1. Narrowness of Perspective. The first problem we encounter when violence is regarded as a crime problem is that it tends then to be regarded as only a crime problem, properly addressed with the usual tools and processes of the criminal justice system. The first difficulty with this narrow view of violence prevention is that current crimmal justice processes do not seem to be very successful in combatting any form of crime, so limiting the campaign against violence to available anti-crime mechanisms is not a promising approach.

The assumption that the rate and seriousness of our lifethreatening violence is a natural outgrowtlı of a high volume of crime and criminals also falsely diagnoses the problem. It is widely believed that the reason the United States suffers particularly from violent crime is that America has so many criminals. ${ }^{54}$ That is, if violence is a crime problem, the most natural and obvious cause is an excessive amount of criminals and whatever social processes may be responsible for that surplus. This diagnosis is demonstrably false.

Recall the comparative incidence of theft, burglary, and robbery in Sydney and Los Angeles. For every ten theft offenses reported in Sydney, Los Angeles reports just over thirteen such offenses. ${ }^{55}$ The supply of thieves in the two communities would seem to be at rough parity. The distribution of one form of aggravated theft, burglary, lends further support to the hypothesis of equivalent criminogenesis-for every ten burglaries reported in

54. See, e.g., Robert Dole, "I Will Restore the Promise of America", Speech Accepting the Nomination for Presidential Candidate at the 1996 Republican National Convention, in WASH. POST, Aug. 16, 1996, at A36 ("I mean to attack the root cause of crime: criminals.").

55. See supra Figures 1-2. 
Sydney, Los Angeles counts nine. ${ }^{56}$ But for every ten robberies reported in Sydney, there are eighty in Los Angeles. ${ }^{57}$ The significant contrast between the two cities does not involve the number of offenders any inore than it involves the number of offenses. It is only the kind of crime that differentiates the cities, so that searching for the causes of crime generally as a means of addressing the particular problein of violence in Los Angeles is barking up the wrong tree.

It is not helpful to respond that the reason other countries have similar crime rates and inuch lower rates of violence is that cities in the United States have different types of criminals and crime. This inerely begs the question of why American crime is so much more likely to include life-threatening violence. The central fact obscured by regarding violence as principally a crime problem is that our rates of lethal violence cannot be implied, predicted, or explained by our general level of crime or population of criminals.

2. The Fallacy of Underinclusion. A related problem is that searching for the sources of violence only in the caseload of the criminal courts will miss inany processes of great importance in generating violence. A propensity for violence is characteristic not only of American crime, but also of many other aspects of American social life. Only a minority of Los Angeles homicides grow out of criminal encounters like robbery and rape. ${ }^{58} \mathrm{~A}$ far greater proportion of Los Angeles homicides grow out of arguments and other social encounters between acquaintances. ${ }^{59}$ At the same time, violent social encounters often go relatively unnoticed-usually, only those arguments that produce great injury and come to the attention of the police are counted in official crime statistics. Most of the processes that generate the risk of lethal violence are not analyzed.

Why should arguments in Los Angeles lead to so inuch inore loss of life than in Sydney? It is likely that the same social tendencies that make crime more dangerous in Los Angeles also

56. See id.

57. See id.

58. Stranger killings in 1992 comprised just under one-third of all cases where the relationship between victim and offender was known ( $24 \%$ of all cases). See FEDERAL BUREAU OF INVESTIGATION, U.S. DEP'T OF JUSTICE, SUPPLEMENTAL HOMICIDE REPORTS 1976-1992 (1st ICPSR version, 1994) (CD-ROM).

59. See id. 
make barroom fights and arguments among co-workers more likely to be life-threatening. The tendency toward life-threatening violence in the Urited States is neither limited to a discrete criminal class nor confined to criminal patterns of behavior. The same social tendencies that predispose American offenders to robbery more often than their foreign counterparts also make arguments more lethal in California than in New South Wales.

Violence in the United States is a problem that is both different from and broader than the problein of criminal offenses in general. The social values and processes that we nuust study to fully understand American violence are unlikely to be confined to those who commit violent crimes. To confine the search for explanations of American violence to criminal behavior and offenders is grossly underniclusive.

3. Diffusion of Focus. If violence in the United States is a nuch broader problein than crime, it is also the case that the range of criminal behavior in America is not limited to violence. Most offenses and inost offenders are not violent. In Los Angeles, for exaniple, only $26 \%$ of index crimes in 1992 involved the use or threat of personal violence. ${ }^{60}$ When nonindex offenses such as drug sales and possession are added, the proportion of crimes involving violence declines to under $15 \%{ }^{61}$

Thus, if only $15 \%$ of crime involves violence, a general anticrime policy will miss the target (if violence is the target) $85 \%$ of the time. A related problem is the lack of any explicit priority given to pumshing and controlling violence. The best illustration of the practical impact of unfocused anti-crime crusades is found in recent American history.

60. See CRME IN THE UNITED STATES 1992, supra note 2, at 94. In 1992, 88,919 crimes were categorized as violent out of a total of 338,531 index crimes reported in Los Angeles. Id.

61. Because violent offenses are more hikely to lead to arrest than nonviolent ones, see INCAPACITATION, supra note 29 , at 89 tbl.5.1, using the percentage of arrests attributable to violence as an index of the percentage of offenses that are violent will overstate the true ratio of violent to nonviolent offenses. But approximately 1.5 million of the $10,949,388$ arrests reported in 1994 were for offenses of violence, or $14 \%$ of the total. See 1994 UNIFORM CRMME REPORTS, supra note 11, at 221 tbl.32. 


\section{B. The Paradoxical Priority Impacts of Crime Wars}

The recent dramatic increase in resources devoted to the punishment of crime ${ }^{62}$ provides a case study of the impact that a general crackdown on crime has on policy toward violent crime. The paradox of the crime crackdown is this: as fear of violence is translated into a general campaign against crime, the share of extra resources that is directed to violent crime will tend to decrease. When penal resources are scarce, the priority given to Inore serious offenses means that violent crimes will receive a large share of the most serious punishments. As a result, expanding punishment resources will have more of an effect on cases of inarginal seriousness than on those that provoke the greatest degree of citizen fear.

Under most criminal justice policies, serious violent crimes result im prison sentences when offenders are apprehended. Armed robbery, attempted murder, and offenses of equivalent magnitude are seriously punished even before special efforts to increase penal severity are imtroduced; no matter how small the prison, we tend to make room for Charles Manson. This pattern of serious punishment means that there is less room left $\mathrm{m}$ the system to get tough with this sort of offense.

Instead, crime crackdowns have their nost dramatic impact on less serious, nonviolent offenses that are close to the margin between incarceration and more leinent penal sanctions. This pattern of nonviolent offenses absorbing the overwhelming majority of resources $\mathrm{m}$ crime crackdowns is clearly illustrated by the recent history of criminal justice policy in the United States. From 1980 to 1990 , for example, the state of California experienced what might be described as the mother of all crime crackdowns. In ten years, the nunber of persons imprisoned in California quadrupled, and the population of those incarcerated in the state's prison and jails increased by over $100,000 .^{63}$

Figure 6 shows the impact of this unparalleled "get tough" policy on the growth in California's prison population as a result of convictions for the four offenses that were profiled in Figures 1 and 2.

62. See FrankLIN E. ZMMRING \& GoRdon HaWkins, THE SCALE OF IMPRISONMENT ch. 5-6 (1991).

63. See Prison POPUlation, supra note 46, at 3-6. 
Figure 6

Percentage Increase in Prisoners by OfFense OF CONVICTION, CALIFORNIA, 1980-199064

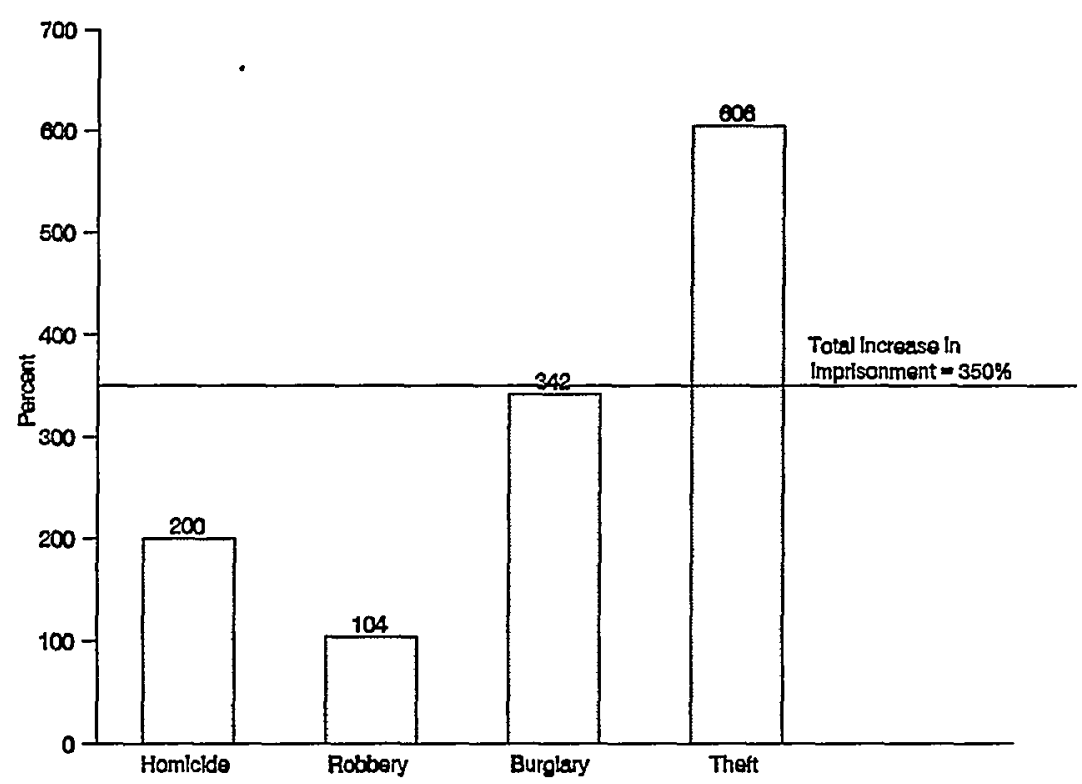

The relative growth in prison population for the two nonviolent offenses is greatly in excess of the growth experienced for robbery and homicide. The relative growth of the number of burglars in prison was over three times that of the number of robbers, and the growth rate of prisoners convicted of theft was over six times the rate for robbers.

The relatively modest impact of California's crime crackdown on violent offenders is not a result of lenient attitudes toward robbery and inurder in California. Quite the opposite; since robbery and murder have always been seriously punished in California, there was a smaller number of leniently treated robbers and killers who had been spared by the previous regime and were thus available to be swept up by the crackdown.

64. See California DeP'T of Corrections, California Prisons 1980 tbls.27A, 27B (1981); California Dep'T of Corrections, California Prisoners and ParolEES tbl.20 (1990). 
This tendency for changes in criminal justice policy to have the most profound effect in marginal cases produced sharp changes in the composition of California's prison population from 1980 to 1990. Sixty percent of all California prison inmates in 1980 had been committed for offenses of violence (i.e., assault, rape, homicide, or robbery); but only $29 \%$ of prisoners added between 1980 and 1990 had been convicted of violent offenses. ${ }^{65}$ If one imagines that the efficiency of an anti-crime pohicy as a way of combattimg violence can be measured by the proportion of offenders imprisoned for violent offenses, the prison resources available in 1980 had a $60 \%$ efficiency rating, while the additional resources committed to imprisonment during the 1980s were employed with $29 \%$ efficiency.

The national pattern is less pronounced, but it also shows that proportions of violent offenders shrink as prison populations increase. In $1979,58 \%$ of the 263,553 persons in state prisons had been convicted of a violent offense. ${ }^{66}$ But only $40 \%$ of the 440,628 additional prisoners that were incarcerated in 1991 had been convicted of crimes of violence. ${ }^{67}$ This diminished overlap between imprisonment and violence is im large measure an inevitable consequence of substantial increases in the proportion of felony offenders sentenced to prison. The current approach creates an enornlous gap between the motive for crime crackdowns and their effects.

For those who wonder why both violence and the rate of imprisonment have been going up, we present the parable of the bait-and-switch advertisement. The practitioner of bait-and-switch

65. Each year, the California Department of Corrections publishes a distribution of prisoners by most serious offense of current conviction. The $60 \%$ figure is derived from that data for 1980; the $29 \%$ estimate was obtained by subtracting 1980 offense specific totals from the 1990 offense-specific totals and then categorizing the offenses as either violent or non-violent. See California DeP'T of Corrections, California Prisons 1980, supra note 64, at tbls. 27A, 27B (1981); CALIFORNIA DEP'T OF CORRECTIONS, CALIFORnia PRIsoners AND PAROleEs, supra note 64, at tbl. 20 (1990).

66. See BUREAU of Justice Statistics, U.S. DeP'T OF Justice, SOURCEBOOK OF CRIMINAL JUSTICE STATISTICS 1987620 tbl.6.39, 638 tbl.6.65 (1988) [hereinafter 1987 SOURCEBOOK].

67. The 1992 Sourcebook of Criminal Justice Statistics reports a total of 328,148 violent offenders in state prisons in 1991 (46.6\% of 704,181). See 1992 SOURCEBOOK, supra note 30 , at 623 tbl. 6.70. The total number of violent offenders estimated in 1979 was 152,861 (58\% of 263,553). See 1987 SourCEBOoK, supra note 66 , at 620 tbl.6.39, 638 tbl.6.65. Thus, the total number of additional violent offense prisoners was 175,287 , or $40 \%$ of the expanded volume. 
selling advertises a brand-new vacuum cleaner with several attractive features for the unheard-of price of $\$ 39.95$. That advertised product is the "bait" designed to lure customers into the store. When the consumer enters the shop, advertisement in hand, he is either told that the advertised special is no longer available or is shown an obviously defective piece of merchandise and actively discouraged froin its purchase. The salesperson then attempts to "switch" the consumer by interesting him in the $\$ 300$ vacuum cleaner that the whole scheme was designed to promote.

The bait-and-switch character of anti-crime crusades is revealed in the contrast between the kind of crime featured in the appeals to "get tough" and the type of offender who is usually on the receiving end of the inore severe sanctions. Willie Horton-the violent criminal-is the "bait" in the usual law-and-order campaign. ${ }^{68}$ But the number of convicted violent predators who are not already sent to prison is rather small. ${ }^{69}$ Thus, the advertised special is unavailable when the customer arrives at the store. The only available targets for escalation in imprisonment pohicy are the marginal offender and the marginal offense. Under these circumstances, to accomplish an increase in rates of arrest, conviction and imprisonment, the target of the pohicy must be "switched" to nonviolent offenders. The result: nonviolent offenders go to prison and citizens wonder why rates of violence continue to increase.

\section{CONCLUSION}

Rates of lethal violence are much higher in the Umited States than in other Western industrial nations, even though rates of common property crimes in the United States are comparable to those found elsewhere. This penchant for life-threatenimg violence cannot be the result of a high volume of either crime or criminals;

68. Horton, a convicted murderer who raped a woman and stabbed her fiancee after escaping from a Massachusetts prisoner furlough program, became a central figure in the 1988 presidential campaign when his story was featured in a campaign advertisement for then-Vice President George Bush criticizing Massachusetts govemor and Democratic candidate Michael Dukakis. See, e.g., Dan Rodricks, Trying to Find the Real Willie Horton, BALT. EvEnING SUN, Aug. 12, 1993, at 1B. The use of Horton's story was attacked for playing on racist fears as well as the fear of violent crime. See id.

69. The Bureau of Justice Statistics reports that $97 \%$ of convicted murderers, $87 \%$ of convicted rapists, $88 \%$ of convicted robbers, $72 \%$ of those convicted of aggravated assault, and $68 \%$ of those convicted of "other violent" offenses are sentenced to incarceration. 1994 SOURCEBOOK, supra note 22, at 487 tbl.5.50. 
if it were, other developed nations with high crime rates would share our higher rate of violence. Other factors must be at work. High rates of robbery, for imstance, cannot come only from rational utility maximization on the part of offenders seeking easy ways to make money by lawbreaking; a taste or preference for violence must explain in part why robbery is a preferred method. In short, American violence is not a crime problem.

Violence is the central concern of those who are afraid of crime. But fear of nonviolent crime such as burglary can increase in response to higher levels of personal violence, as citizens project the murderous intentions they fear most onto a broad range of crimes and criminals. This process of categorical contagion infects the public's perception of crines that in fact involve hittle objective risk of violence.

Categorical contagion leads voters and policymakers to conflate violent crime with crime in general. But "getting tough" on crime im general is inadequate as an anti-violence strategy. If lethal violence is the primary target of governmental concern, the anti-crime crackdown is mefficient, diffuse in focus, and misses the opportunity to look beyond the category of criminal behavior for the sources of, and means to control, violence. The slight impact of the last decade's significant increase in penal confinement has demonstrated the inefficiency of anti-crime crusades as a means of combatting violence. Until lethal violence is addressed specifically, undifferentiated fear of crime will hobble efforts to prevent the violent acts that are the root cause of this fear. 